\title{
Missing seashells: a subtle detail of an inadequate policy
}

\author{
Conchas do mar ausentes: um detalhe sutil de uma política inadequada \\ Conchas marinas faltantes: un detalle sutil de una política inadecuada
}

Received: 10/13/2021 | Reviewed: 10/20/2021 | Accept: 10/25/2021| Published: 10/28/2021

\author{
Laura Roberta Sarmento de Barros \\ ORCID: https://orcid.org/0000-0003-0559-7259 \\ Universidade Santa Cecília, Brazil \\ E-mail: laurarsbarros@gmail.com \\ Walter Barrella \\ ORCID: https://orcid.org/0000-0001-9038-7840 \\ Universidade Santa Cecília, Brazil \\ Universidade Paulista, Brazil \\ E-mail: walterbarrella@gmail.com \\ Miguel Petrere Jr. \\ ORCID: https://orcid.org/0000-0003-2000-6699 \\ Universidade Santa Cecília, Brazil \\ Universidade Federal do Pará, Brazil \\ E-mail: mpetrerejr@gmail.com \\ Davi Butturi-Gomes \\ ORCID: https://orcid.org/0000-0002-8398-533X \\ Universidade Santa Cecília, Brazil \\ Universidade Federal de São João del-Rei, Brazil \\ E-mail: davi.butturi@gmail.com
}

\begin{abstract}
In Santos Beach, southwest coast of Brazil, cleaning operations are intensified during the summer using manual and mechanical techniques, driven mainly by sanitary and aesthetic aspects that neglect basic ecological standards. This study evaluated the abundance, richness, and diversity of dead shells, after spring and neap tides, found in two strips of sandy beaches: the "damp" and the "wet "sectors, where only the former undergoes mechanical cleaning. We collected and counted all fragmented and whole shells, identified each down to the species levels, and measured their weight. We used mixed statistical modeling to evaluate the effect of the sector over the abundance (in weight and number), richness, and Shannon-Wiener diversity $\left(H^{t}\right)$. We found a significantly greater abundance of fragmented shells in the damp sector. Since this is the sector where mechanical cleaning is applied, we understand such a strategy promotes potential harmful impacts over the conchological structure in Santos Beach, requiring mitigatory measures to protect empty shells. Finally, we fathom incorrectly discarded litter is brought from the surrounding mangrove to the beach after the spring tides; thus, integrated cleaning management with the participation of the local population, are also required to reduce the mechanical cleaning and its impacts.
\end{abstract}

Keywords: Beach cleaning; Cleaning tractors; Conchology; Environmental impact; Shell fragmentation; Tides.

\section{Resumo}

Na Praia de Santos, litoral sudoeste do Brasil, as operações de limpeza são intensificadas durante o verão por meio de técnicas manuais e mecânicas, orientadas principalmente por aspectos sanitários e estéticos que negligenciam os padrões ecológicos básicos. Este estudo avaliou a abundância, riqueza e diversidade de conchas mortas, após as marés de sizígia e marés de quadratura, encontradas em duas faixas de areia da praia arenosa: o setor "úmido" e o "molhado", onde apenas a primeira passa por limpeza mecânica. Coletamos e contamos todas as conchas fragmentadas e inteiras, identificamos cada uma até o nível de espécie e medimos o seu peso. Usamos modelagem estatística mista para avaliar o efeito do setor sobre a abundância (em peso e número), riqueza e diversidade de Shannon-Wiener $\left(\mathrm{H}^{\prime}\right)$. Encontramos uma abundância significativamente maior de conchas fragmentadas no setor úmido. Por se tratar do setor de aplicação da limpeza mecânica, entendemos que tal estratégia promove potenciais impactos deletérios sobre a estrutura conquiliológica da Praia de Santos, exigindo medidas mitigadoras para proteção de conchas. Finalmente, calculamos que o lixo descartado incorretamente é trazido do mangue circundante, para a praia, após as marés de sizígia; assim, a gestão integrada da limpeza com a participação da população local, também são essenciais para reduzir a limpeza mecânica e seus impactos.

Palavras-chave: Limpeza de praias; Tratores de limpeza; Conquiliologia; Impacto ambiental; Fragmentação de conchas; Marés. 


\section{Resumen}

En Playa de Santos, en la costa suroeste de Brasil, las operaciones de limpieza se intensifican durante el verano a través de técnicas manuales y mecánicas, orientadas principalmente por aspectos sanitarios y estéticos que descuidan los estándares ecológicos básicos. Este estudio evaluó la abundancia, riqueza y diversidad de conchas muertas, como mareas vivas y mareas en cuadratura, encontradas en dos franjas de arena de la playa arenosa: el sector "húmedo" y el "húmedo", por donde solo pasa la primera. limpieza mecánica. Recolectamos y contamos todas las conchas rotas y enteras, identificamos cada una hasta el nivel de la especie y medimos su peso. Utilizamos modelos estadísticos mixtos para evaluar el efecto del sector sobre la abundancia (en peso y número), riqueza y diversidad de ShannonWiener ( $\left.\mathrm{H}^{\prime}\right)$. En el sector húmedo se encontró una importante enfermedad crónica de las conchas fragmentadas. Por tratarse del sector de aplicación de la limpieza mecánica, entendemos que esta estrategia promueve impactos deletéreos en la estructura del caparazón de Praia de Santos, requiriendo medidas de mitigación para proteger los caparazones. Finalmente, calculamos que la basura desechada incorrectamente se trae del manglar relacionado a la playa después de las mareas de primavera; por ello, la gestión integral de la limpieza con la participación de la población local también es fundamental para reducir la limpieza mecánica y sus impactos.

Palabras clave: Limpieza de playas; Limpieza de tractores; Conquilología; Impacto ambiental; Fragmentación de conchas; Mareas.

\section{Introduction}

Beaches are regions of accumulation of unconsolidated sediments, transported and shaped according to the movements of waves, ranging from the limits established by low and high tides. Such habitats are sand, stones, pebbles, or shells (Correia \& Sovierzoski, 2005; Lopes, Milanelli \& Poffo, 2007). The formers are remnants of marine animals, structures of rigid exoskeleton that shelter soft and fragile mollusks, which need to protect themselves from predators and withstand water pressure (Absalão \& Pimenta, 2005; O' Connor \& Crowe, 2005; Balvanera et al., 2006; Cardinale et al., 2006). These remains play an essential role in nutrient cycling (Kowalewski et al., 2000) and may serve as shelters for other small animals when empty (Hall-Spencer et al., 2003).

Marine coastlines are habitats particularly vulnerable to human activity, subjected to intensified impacts due to leisure activities on the beaches, the use of recreational and cleaning vehicles, camping, intense trampling, garbage disposal, and shell removal as well. Long-term studies on human impacts on coastal habitats are scarce and discontinuous, especially on the conchological structure, a poorly understood and understudied subject (Defeo et al., 2009; Ramírez, Tuya \& Haroun, 2009).

In this context, one of the pending questions is how the techniques used to clean beaches relate to environmental impacts. The cleaning procedures are, in general, economic-driven, and the people responsible for them, either in public or private agencies, are primarily concerned with aesthetic and sanitary issues, ignoring ecological components, and possibly deepening harmful impacts on the biota and ecosystem services (Michel, Shigenaka \& Hoff; Milanelli \& Lopes, 2001; Cordeiro et al., 2018). For instance, Santos (2020) argues that aesthetic-oriented beach sanitation promotes soil compaction, which crushes living organisms and alters the natural composition of the deposited material. Thus, sustainable solutions are needed to balance between recreational interests and environmental concerns in coastal landscapes, i.e., society urges for reducing the environmental impacts caused by human activities while respecting economic and tourism uses of beaches (Kelly, 2016). This, in turn, makes evaluations of the effects of cleaning procedures on the conchological structure a strategic step.

At Santos beach, cleaning tractors operate from 4 am to remove solid waste deposited by spring tides in the damp sand strip, farthest from the waterline, while in the wet sector, closest to the waterline, cleaning is only manual. According to Cordeiro (2016), in the summer period, Santos City Hall hires more people to clean the beaches, who carry out the process more than once per day. Thus, cleaning is more rigorous and frequent in the summer, when duplicates the number of employees, and a mechanical rake is used to clean the wet sand strip (Prefeitura Municipal de Santos, 2019), despite numerous studies pointing the ecological impacts of such practices (Griffin, 2018). Following the rationale in Griffin (2018), these studies nonetheless have not yet sufficiently explored how cleaning techniques may interact with environmental factors; for 
instance, the tidal regimen may influence the deposit of different sizes of shells, debris, litter, and whatnot, and successful management programs should take this in consideration as well.

Since the marks left by the tires of the tractors on Santos Beach (Brazil) show a path of fragmented shells, broken due to the tractor weight and the typical tidal dynamics, the hypotheses we raised in this study were: (i) decreased abundances of whole shells (and increased abundance of fragmented shells) in the damp sector (subjected to both mechanical and manual cleaning) compared to the wet sector (subjected to manual cleaning only); (ii) decreased abundances reflect in decreased richness and diversity; and (iii) the abundance, richness, and diversity of shells in spring tides are more expansive when compared to neap tides.

\section{Methodology}

\subsection{Study area}

The "Baixada Santista" (São Paulo, Brazil) comprises an area of 2,422km² (24⒉ $24^{\prime \prime S}, 47^{\circ} 00^{\prime} 18^{\prime \prime} \mathrm{W}$ to $23^{\circ} 45^{\prime} 30^{\prime \prime S}$, 45 52'14"W), covering nine coastal municipalities: Bertioga, Cubatão, Guarujá, Itanhaém, Mongaguá, Peruíbe, Praia Grande, Santos, and São Vicente. It has 1.7 million people, which increases considerably during the summer (December to March). The climate in the region is hot and humid tropical, the average annual temperature is above $20^{\circ} \mathrm{C}$, and rainfall ranges from 2,000 $\mathrm{mm}$ to 4,500 $\mathrm{mm}$ per year (Moser et al., 2005). All beaches are dissipative and have sub-horizontal slopes (inclination $<10^{\circ}$ ). (Magini et al., 2007). Santos beach is crossed by six drainage channels, each serving as a border between any two neighborhoods (Figure 1). 
Figure 1: The map of Praia de Santos highlights the drainage channels' location (numbers 1 to 6) and the deposition and erosion zones (Zone 1 and Zone 2, respectively).

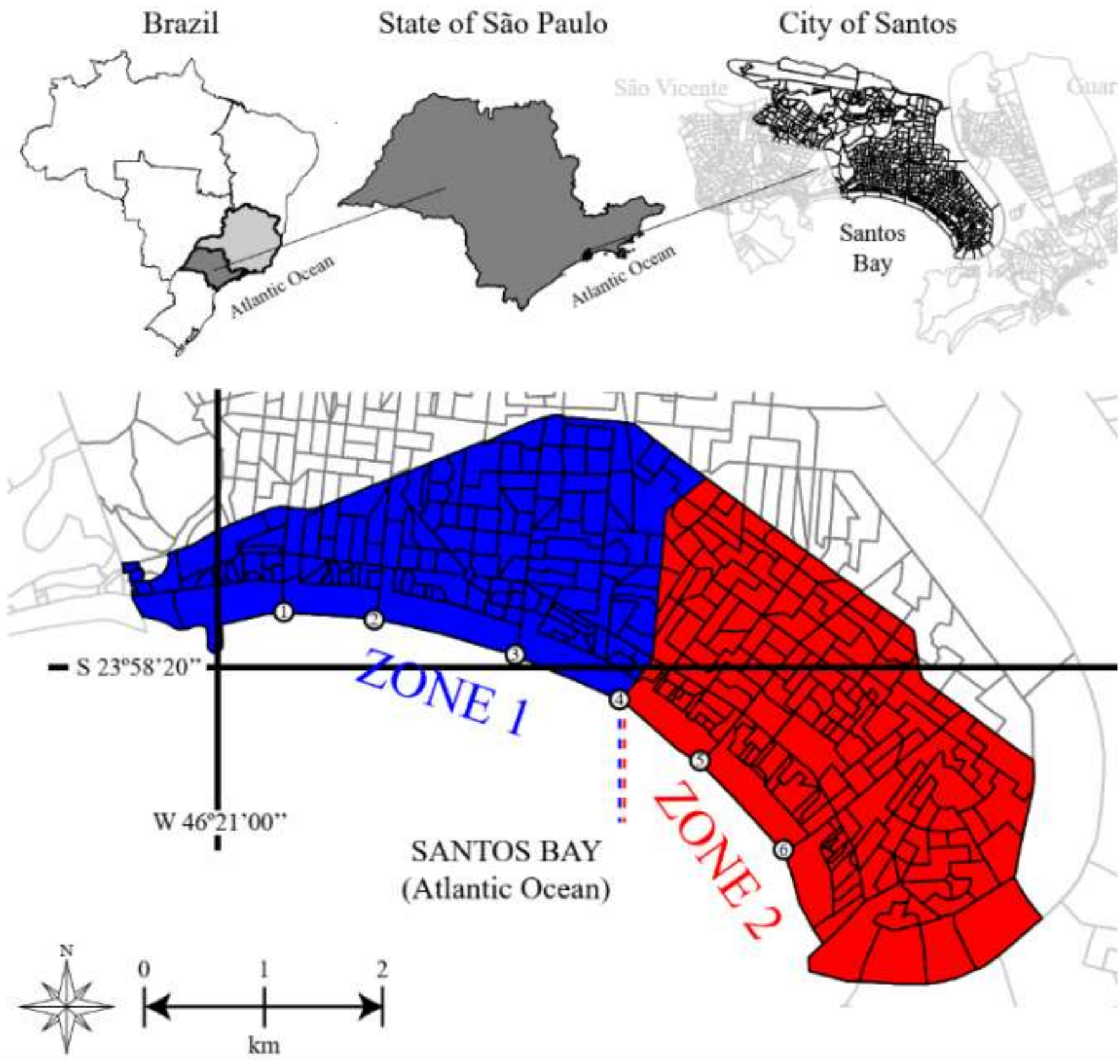

Source: Authors.

\subsection{Sample design and data collection}

This research is quantitative-experimental in nature, as a way to test the veracity of the hypotheses that were raised (Koche, 2011). In total, we performed eight outings (or campaigns) to collect the shells, alternating two days during spring tides and two days during neap tides, totaling 96 sampling events in the summer of 2019/2020. At each campaign, we collected shells in two zones: deposition zone (Z1), where currents and tides bring sediment deposits, and erosion zone (Z2), where the sand is withdrawn continuously. Channel 4 is the limit across Z1 and Z2 (Figure 1).

We divided the zones into transects of approximately $100 \mathrm{~m}$ in width, starting in the wet strip of sand. We carried out simple, independent random draws of six transects at each collection event, three for each zone. Within each transect, we took two samples, each comprised of a one $\mathrm{m}^{2}$ plot, one in the damp sector and one in the wet sand sector. A schematic 
representation of the sample design is available in Figure 2. In line with the method we adopted here (i.e., the erosion/deposition zone separation), Morton et al. (2011) carried out a study in Australia and highlighted the importance of comparing impacts within the exact location to investigate the potential effects of mechanical beach cleaning: they argue that comparisons made among different beaches, often located at long distances from one another, whose effects might be attributed to cleanliness, actually lies in differences of their physical characteristics.

We collected fragmented and whole shells from the surface, washed them on the spot, stored them in labeled plastic bags, and took them to the laboratory. In the laboratory, we manually washed all material and accommodated it for drying. We weighed all shells within each sampling unit in sequence, using a portable digital scale (precision of $0.1 \mathrm{~g}$ ). Finally, we used printed manuals of Lindner (2000), and Gil et al. (2010), and the specialized website Conquiliologistas do Brasil (1989) to identify shell species. Our dataset is available in Barros et al. (2020).

Figure 2: Sample design - drawing of three transects ( $\mathrm{T} 1$ to $\mathrm{T} 6$ ) for each zone ( $\mathrm{Z} 1$ and $\mathrm{Z} 2$ ), withdrawing of $1 \mathrm{~m}^{2}$ (a to f) sample units in the wet and humid sand sectors, totaling an effort of $6 \mathrm{~m}^{2}$ per zone at each exit.

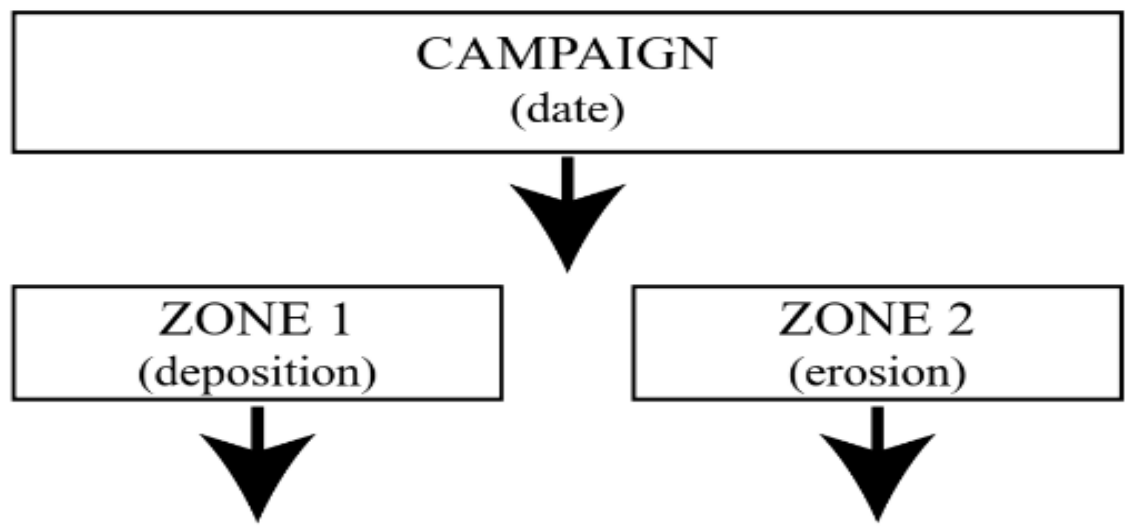

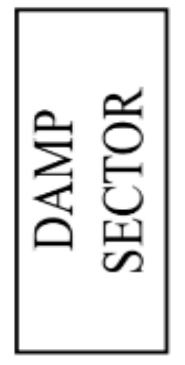

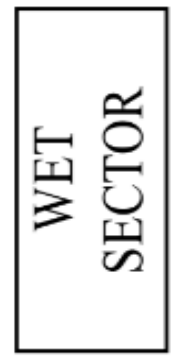

(a)

(b)
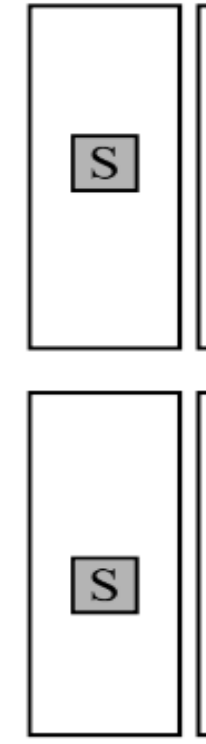

(c)
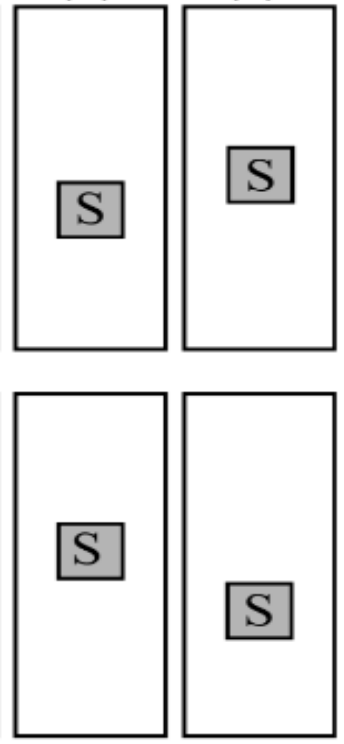

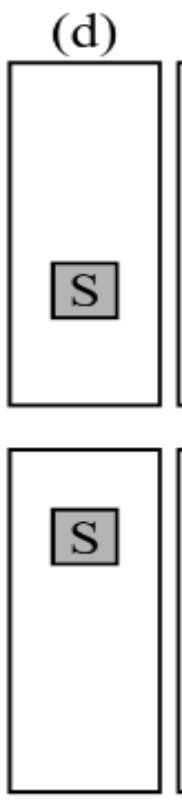

(e)

(f)
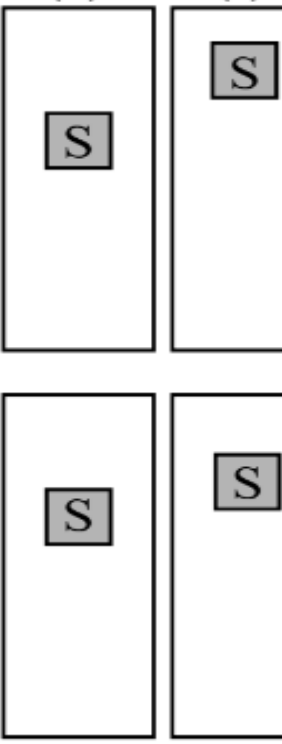

\subsection{Statistical analysis}

Source: Authors.

We fitted delta-lognormal mixed models to the weights of fragmented shells, whole shells, and their total weight, without distinction of species and individual (Eggers, 2015; Lo, Jacobson \& Squire, 1992; Min \& Agresti, 2002). These models are exceptional cases of two-stage models for semi-continuous variables. In the first stage, one assumes a binomial 
distribution for the presence-absence vector and, in the second stage, non-zero observations are subjected to a logarithmic transformation with standard assumptions of the classic linear model (independence, normality, homoscedasticity).

Notably, in our study,

$$
\begin{aligned}
& \Pi_{\mathrm{ij} j(d e f)} \mid a_{\text {def }}, a_{\text {de }}, a_{d} \quad \sim \operatorname{Binomial}\left(1, \lambda_{i j k[\text { def })}\right) \\
& \log Y_{i j k(d e f)} \mid \Pi_{i j k \text { (def) }}=1, b_{d e f}, b_{d e^{x}}, b_{d} \sim \operatorname{Nomal}\left(\mu_{i j k[d e f)}, \sigma^{2}\right)
\end{aligned}
$$

where $\Pi_{\mathrm{i} j k[d e f]}$ is the random variable in the $i$-th replicate of the $j$-th tide level of the $k$-th sector level, which describes the process of producing zeros in the dataset, with probability $\lambda_{i j k \text { kef })}$, conditioned on the random effects of the $f$-th transect $(\mathrm{f}=$ $\{1, \ldots, 6\}$ ), nested in the $e$-th sampling zone (deposition or erosion), nested in the $d$-th campaign (date of collection), denoted by the latent random variables (i.e., not directly observable) $a_{d e f}, a_{d e}$ and $a_{d}$, all supposedly with the normal distribution of

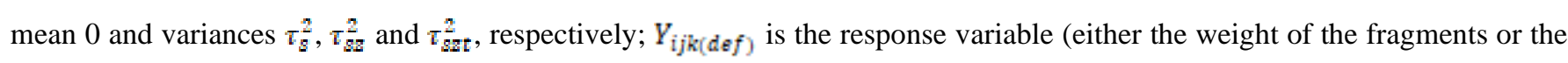
weight of the shells or the total weight), conditioned both on a positive observation (i.e., when $\Pi_{i j k[d e f)}=1$ with probability $\lambda_{i j k \text { (def) }}$ ) and on the random effects $b_{d e f}, b_{d e}$, and $b_{d}$, mutually independent from $a_{d e f}, a_{d e}$ and $a_{d \in}$, and also supposedly normally distributed with mean 0 and variances $\sigma_{g}^{2}, \sigma_{s z}^{2}$ and $\sigma_{s z t}^{2}$. Therefore, the initial predictors of the mixed delta-lognormal models were

$$
\begin{aligned}
\operatorname{logit}\left(\lambda_{i j k[d e f)}\right) & =a_{0}+a_{1 j}+a_{2 k}+\alpha_{2 j k}+a_{d e}+a_{d e}+a_{d e f} \\
\mu_{i j k[d e f)} & =\beta_{0}+\beta_{1 j}+\beta_{2 k}+\beta_{3 j k}+b_{d}+b_{d e}+b_{d e f}
\end{aligned}
$$

where $\alpha_{0}$ and $\beta_{0}$ are the intercepts of the binomial and lognormal stages, respectively; $\alpha_{1 j}$ and $\beta_{1 j}$ are the fixed effects of the $j$-th tide level $(j=\{1,2\}) ; \alpha_{2 k}$ and $\beta_{2 k}$ are the fixed effects of the $k$-th level of the sampling sector $(k=\{1,2\}) ; \alpha_{a j k}$ and $\beta_{a j k}$ are the fixed effects of the interaction between tide and sampling sector and $a$, and $b$. correspond to the random effects described above, used here to accommodate both the possible heterogeneity between sampling units and the structure of the quasi-experiment, similar to a split split-plot design (Pimentel-Gomes, 2009). For the estimation process, we used restricted maximum likelihood and the restrictions $\alpha_{11}=\beta_{11}=\alpha_{21}=\beta_{21}=\alpha_{211}=\beta_{211}=0$, such that, effectively, the main effects $\alpha_{12}$ and $\beta_{12}$ refer to the effects of spring tide, the main effects $\alpha_{22}$ and $\beta_{22}$ refer to the effects of the damp sector, and $\alpha_{222}$ and $\beta_{222}$ are interaction effects between spring tide and the damp sector. In the cases in which the response variable did not have zeros (or had a frequency of zeros so low to prevent the convergence of the estimation process), the binomial stage was discarded, implying a lognormal mixed model.

After fitting the initial model for each response variable, we performed likelihood ratio tests to assess whether the inclusion of a given effect in the final model was desirable. Thus, firstly, we selected the random effects, which is equivalent to assessing whether one (or more) variance components $\left(\tau_{s}^{2}, \tau_{s z}^{2}\right.$ e $\tau_{s z t}^{2}$ in the binomial stage, and $\sigma_{s}^{2}, \sigma_{s z}^{2}$ e $\sigma_{s z t}^{2}$ in the lognormal stage) is null. After deciding on the structure for the random effects, we executed the selection of the fixed effects (Pinheiro \& Bates, 2000).

Regarding the count data (number of fragmented and whole shells and their summation), we adopted a similar approach, i.e., we fitted generalized linear mixed models, using the same initial predictors for the second stage of the deltalognormal model. Conversely, as the response variables, in this case, are discrete, we considered the Poisson and the Negative Binomial distributions for the random component of the model, using, in both cases, a logarithmic link function. The Negative Binomial distribution has an extra parameter $(\kappa)$ to accommodate for overdispersion (counts where the mean is greater than the 
variance), in contrast to the Poisson distribution that imposes equality between these moments (Hinde \& Demétrio, 1998; Lawless, 1987).

Since the individuals in each sampling unit were identified to the species level, we also calculated richness and the Shannon-Wiener diversity index $\left(H_{j}^{p}=-\sum p_{\mathrm{i} j} \ln p_{\mathrm{i} j}\right.$, where $p_{\mathrm{i} j}$ is the ratio between the number of individuals belonging to the $i$-th species and the total number of individuals observed in the $j$-th sampling unit). Thus, we fitted statistical models for these response variables: for richness, Poisson, and Negative Binomial mixed models (logarithmic link) and, for diversity, delta-lognormal mixed models were considered. Similarly, the initial predictors of the previous models were as described above, and we applied the same procedures for selecting effects. We used residual analyses to validate all models, particularly quantile-quantile plots with $95 \%$ confidence simulated envelopes.

We adopted a significance level of $5 \%$ in all statistical analyses and conducted all analyses in R version 3.6.3 (R Core Team, 2019), using the packages' hnp' (Moral, Hinde \& Demétrio, 2017), 'Ime4' (Bates et al., 2015) and 'vioplot' (Adler \& Thomas Kelly, 2019).

\section{Results}

We verified that shells belonged to either Bivalvia or Gastropoda in the pooled sample, adding up to 16 families, 23 genera, and 29 species. The Bivalvia class was the most representative, with the most remarkable species richness for the Veneridae family. The most abundant species were: Mulinia cleriana, which belongs to the Mactridae family, with $38.40 \%$, followed by Anadara ovalis with 25.46\%, and Anadara brasiliana (11.81\%), both from the Arcidae family. The Gastropoda class accounted for only $1.2 \%$ of the collected specimens, presenting only three species, and Melanoides tuberculatus was the only freshwater one collected in the erosion zone, in a humid sector located next to a drainage channel.

We detected significant differences between sectors and between tides for the abundance in weight of fragmented shells (Figure 3A, Table 1), while the abundance of fragmented shells (Figure 3B, Table 2) presented significant differences between sectors only. Even though the pattern of significant differences occurred for the weights of whole shells (Figure 3C, Table 3) and their respective counts (Figure 3D, Table 4), the opposite sign of the parameter $\beta_{22}$ is noteworthy (negative for whole shells and positive for fragmented ones). This shows that greater abundances of whole shells are expected in the wet sector, and, conversely, greater abundances of fragmented shells are expected in the damp sector. 
Figure 3: Violin plots of the observed abundances of fragmented and whole shells according to sector and tide. A: non-zero weights of fragmented shells; B: counts of fragmented shells; C: non-zero weights of the whole shells; D: counts of whole shells.

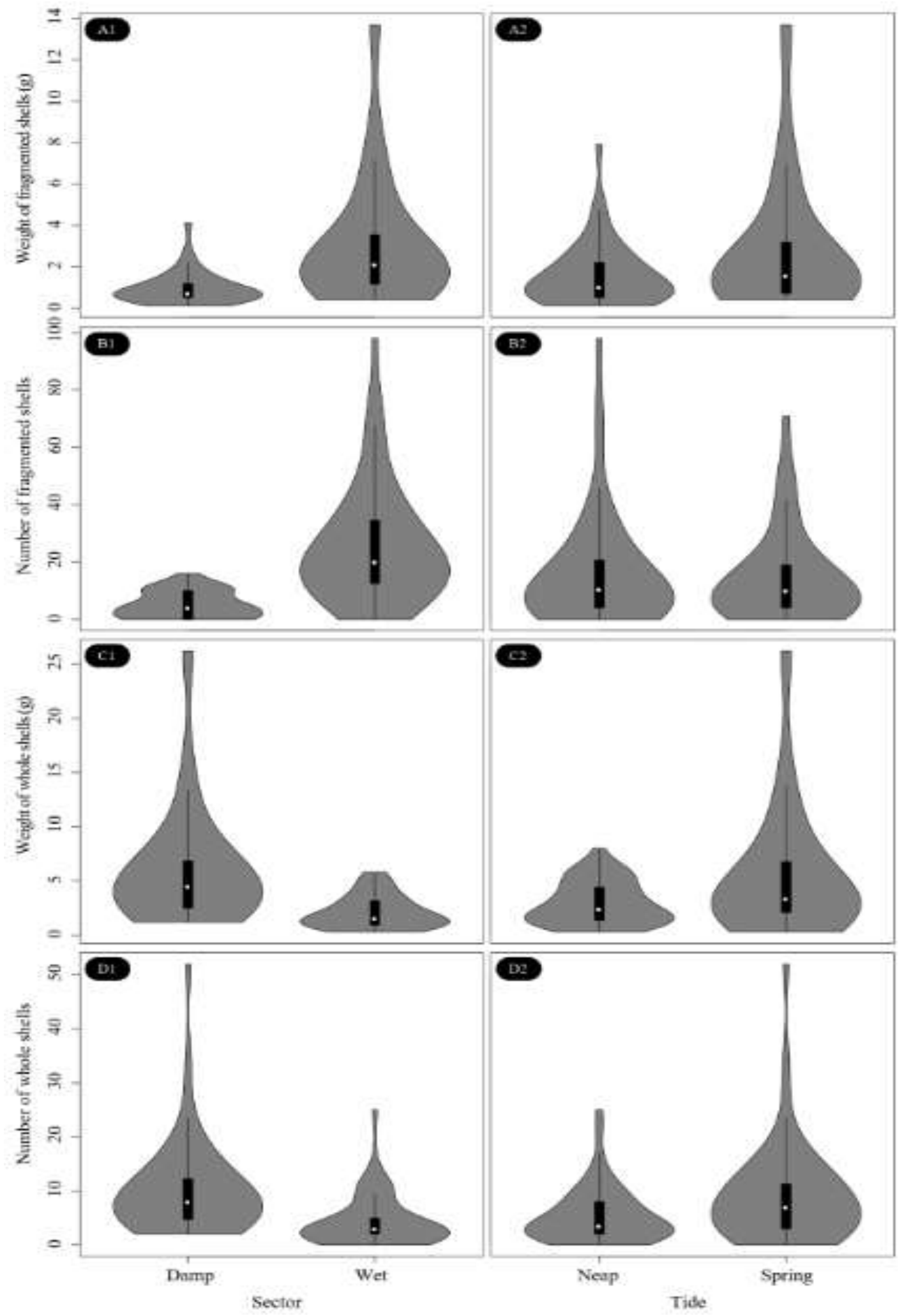

Source: Authors. 
Table 1: Estimates of the final delta-lognormal mixed model fitted to the weights of fragmented shells. $\alpha_{0}$ and $\beta_{0}$ are the intercepts of each stage; $\beta_{12}$ refers to the spring tide effect; $\alpha_{22}$ and $\beta_{22}$ refer to the effects of the damp sector; $\sigma_{\mathrm{z}}$ and $\tau_{\mathrm{z}}$ are the standard deviations of the random zone effects; $\sigma_{\mathrm{zt}}$ and $\tau_{\mathrm{zt}}$ are the standard deviations of the random effects of transect nested in the zone, and $\sigma$ is the residual standard deviation.

\begin{tabular}{cccccc}
\hline \multicolumn{5}{c}{ Binomial stage } \\
\hline Parameter & Estimate & SE & DF & $|Z|$ & $p$ Value \\
$\alpha_{0}$ & 1.0605 & 0.6933 & - & 1.530 & 0.12612 \\
$\alpha_{22}$ & 3.1777 & 1.0763 & - & 2.953 & 0.00315 \\
$\tau_{\mathrm{zt}}$ & 0.5356 & & & & \\
$\tau_{\mathrm{z}}$ & 0.7701 & & & \\
\hline \multicolumn{5}{c}{ Lognormal stage } \\
\hline Parameter & Estimate & SE & DF & $|t|$ & $p$ Value \\
$\beta_{0}$ & -0.6037 & 0.3789 & 1.2629 & 1.594 & 0.3171 \\
$\beta_{12}$ & 0.4512 & 0.1617 & 74.3716 & 2.790 & 0.0067 \\
$\beta_{22}$ & 1.1133 & 0.1649 & 75.3027 & 6.753 & $<0.0001$ \\
$\sigma_{\mathrm{zt}}$ & 0.09998 & & & & \\
$\sigma_{\mathrm{z}}$ & 0.48853 & & & & \\
$\sigma$ & 0.72703 & & &
\end{tabular}

Source: Authors.

Table 2: Estimates of the final mixed negative binomial model fitted to the counts of fragmented shells. $\beta_{0}$ is the model intercept; $\beta_{22}$ refers to the effect of the damp sector; $\sigma_{\mathrm{z}}$ is the standard deviation of the zone random effect, and $\kappa$ is a super dispersion parameter.

\begin{tabular}{ccccc}
\hline Parameter & Estimate & SE & $|Z|$ & $p$ Value \\
\hline$\beta_{0}$ & 1.6064 & 0.2520 & 6.376 & $<0.0001$ \\
$\beta_{22}$ & 1.5919 & 0.1779 & 8.948 & $<0.0001$ \\
$\sigma_{\mathrm{z}}$ & 0.303 & & & \\
$\kappa$ & 1.5693 & & & \\
\hline
\end{tabular}

Source: Authors. 
Table 3: Estimates of the final lognormal model mixed fitted to the weights of whole shells. $\beta_{0}$ is the model intercept; $\beta_{12}$ refers to the spring tide effect; $\beta_{22}$ refers to the effect of the damp sector; $\sigma_{\mathrm{z}}$ is the standard deviation of the zone random effect and $\sigma$ is the residual standard deviation.

\begin{tabular}{cccccc}
\hline Parameter & Estimate & SE & DF & $|t|$ & $p$ Value \\
$\beta_{0}$ & 1.3126 & 0.3315 & 1.1971 & 3.960 & 0.12504 \\
$\beta_{12}$ & 0.4246 & 0.1422 & 86.0047 & 2.987 & 0.00367 \\
$\beta_{22}$ & -1.0304 & 0.1424 & 86.0051 & 7.2233 & $<0.0001$ \\
$\sigma_{\mathrm{z}}$ & 0.4367 & & & & \\
$\sigma$ & 0.6738 & & & & \\
\hline
\end{tabular}

Source: Authors.

Table 4: Estimates the final negative binomial mixed model fitted to the count of whole shells. $\beta_{0}$ is the model intercept; $\beta_{22}$ refers to the effect of the damp sector; $\sigma_{\mathrm{s}}$ is the standard deviation of the random output effect (collection date); $\sigma_{\mathrm{sz}}$ is the standard deviation of the random effect for zone nested in campaign; $\sigma_{\mathrm{szt}}$ is the standard deviation of the random effect for transect, nested in zone, nested in campaign; and $\kappa$ is the overdispersion parameter.

\begin{tabular}{ccccc}
\hline Parameter & Estimate & SE & $|\mathrm{Z}|$ & $p$ Value \\
\hline$\beta_{0}$ & 2.1055 & 0.1523 & 13.822 & $<0.0001$ \\
$\beta_{22}$ & -0.8671 & 0.1221 & 7.101 & $<0.0001$ \\
$\sigma_{\mathrm{szt}}$ & 0.4620 & & & \\
$\sigma_{\mathrm{sz}}$ & 0.4455 & & & \\
$\sigma_{\mathrm{z}}$ & 0.0001 & & & \\
$\kappa$ & 6.3207 & & & \\
$\kappa$
\end{tabular}

Source: Authors.

Following the pattern observed for the weights of whole shells, we found significant differences between sectors and between tides in the final model fitted to the total weight (Figure 4A, Table 5), favoring greater expected total weights in the wet sector during spring tides. Although this was also the case for the total counts (Figure 4B, Table 6), we found a significant antagonist interaction effect between the wet sector and spring tide.

According to the fitted model, species richness is expected to be more numerous in the wet sector when compared to the damp section (Figure 4C, Table 7). Finally, tides did not significantly affect neither species richness nor diversity, and we found no significant effects to influence diversity, despite greater observed values of $H^{*}$ in the wet sector (Figure 4D, Table 8). 
Figure 4: Violin plots of the observed distributions for the total abundance in weight (A), total abundance in number (B); species richness (C) and for Shannon-Wiener diversity index (D), according to sector and tide.

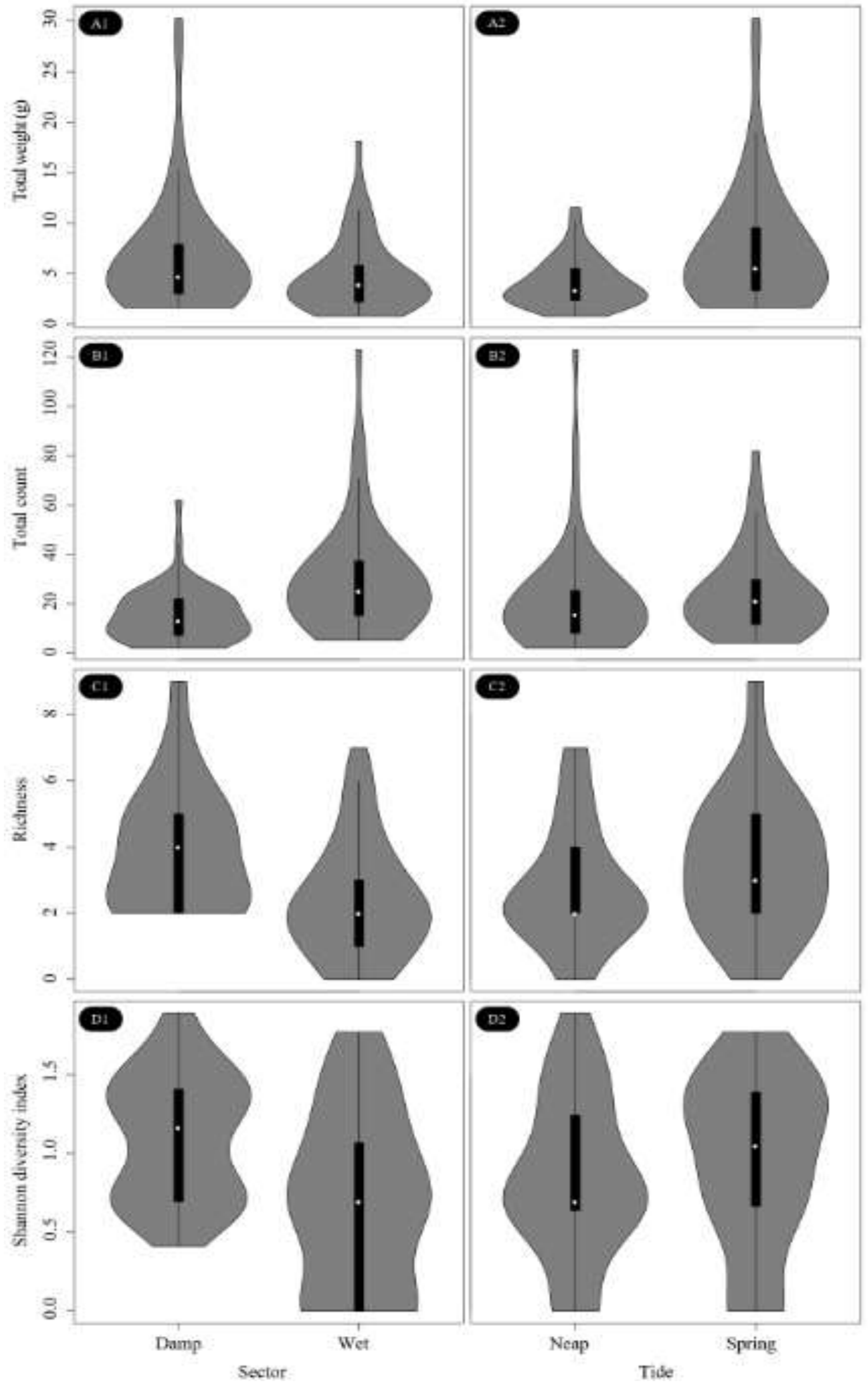

Source: Authors. 
Table 5: Estimates of the final lognormal mixed model fitted to the total weight. $\beta_{0}$ is the model intercept; $\beta_{12}$ refers to the spring tide effect; $\beta_{22}$ refers to the effect of the damp sector; $\sigma_{\mathrm{zt}}$ is the standard deviation of the random effect of transect nested in a zone; $\sigma_{z}$ is the standard deviation of the zone random effect, and $\sigma$ is the residual standard deviation.

\begin{tabular}{cccrcc}
\hline Parameter & Estimate & SE & DF & $|t|$ & $p$ Value \\
$\beta_{0}$ & 1.4082 & 0.3512 & 1.1094 & 4.010 & 0.13636 \\
$\beta_{12}$ & 0.5021 & 0.1117 & 88 & 4.495 & $<0.0001$ \\
$\beta_{22}$ & -0.3058 & 0.1117 & 88 & -2.738 & 0.00749 \\
$\sigma_{\mathrm{zt}}$ & 0.1103 & & & & \\
$\sigma_{\mathrm{z}}$ & 0.4732 & & & & \\
$\sigma$ & 0.5472 & & & & \\
\hline
\end{tabular}

Source: Authors.

Table 6: Estimates of the final mixed negative binomial model parameters fitted to the total counts (summation of the fragmented and whole shells). $\beta_{0}$ is the model intercept; $\beta_{12}$ refers to the effect of spring tide; $\beta_{22}$ refers to the effect of the damp sector; $\beta_{322}$ refers to the effect of the interaction between spring tide and damp sector; $\sigma_{z}$ is the standard deviation of the random effect for zone; $\sigma_{z t}$ is the standard deviation of the random effect for transect nested in zone, and $\kappa$ is the overdispersion parameter.

\begin{tabular}{ccccc}
\hline Parameter & Estimate & SE & $|Z|$ & $p$ Value \\
\hline$\beta_{0}$ & 2.4203 & 0.2693 & 8.989 & $<0.0001$ \\
$\beta_{12}$ & 0.4396 & 0.1749 & 2.514 & 0.0119 \\
$\beta_{22}$ & 0.9603 & 0.1724 & 5.571 & $<0.0001$ \\
$\beta_{322}$ & -0.5022 & 0.2415 & 2.080 & 0.0375 \\
$\sigma_{\mathrm{zt}}$ & 0.1209 & & & \\
$\sigma_{\mathrm{z}}$ & 0.3289 & & & \\
$\kappa$ & 3.4256 & & & \\
\hline
\end{tabular}

Source: Authors.

Table 7: Estimates of the final Poisson mixed model fitted to species richness. $\beta_{0}$ is the model intercept; $\beta_{22}$ refers to the effect of the damp sector; $\sigma_{\mathrm{z}}$ is the standard deviation of the random effect for zone; $\sigma_{\mathrm{zt}}$ is the standard deviation of the random effect for transect nested in zone.

\begin{tabular}{ccccc}
\hline Parameter & Estimate & SE & $|Z|$ & $p$ Value \\
\hline$\beta_{0}$ & 1.3493 & 0.1480 & 9.116 & $<0.0001$ \\
$\beta_{22}$ & -0.4958 & 0.1180 & 4.210 & $<0.0001$ \\
$\sigma_{\mathrm{zt}}$ & 0.1195 & & & \\
$\sigma_{\mathrm{z}}$ & 0.1679 & & & \\
\hline
\end{tabular}

Source: Authors. 
Table 8: Estimates of the final delta-lognormal mixed model fitted to the Shannon-Wiener diversity index. $\alpha_{0}$ and $\beta_{0}$ are the intercepts of each stage; $\alpha_{22}$ refers to the effect of the damp sector; $\sigma_{\mathrm{z}}$ is the standard deviation of the random effect for zone; $\sigma_{\mathrm{zt}}$ is the standard deviation of the random effect for transect nested in zone, and $\sigma$ is the residual standard deviation.

\begin{tabular}{cccccc}
\hline \multicolumn{7}{c}{ Binomial stage } \\
\hline Parameter & Estimate & SE & DF & $|\mathrm{Z}|$ & $p$-Value \\
\hline$\alpha_{0}$ & 19.57 & 1552.21 & - & 0.013 & 0.99 \\
$\alpha_{22}$ & -18.78 & 1552.21 & - & 0.012 & 0.99 \\
\multicolumn{7}{c}{ Lognormal stage } \\
\hline Parameter & Estimate & SE & DF & $|t|$ & $p$ Value \\
\hline$\beta_{0}$ & -0.01404 & 0.14235 & 0.99959 & 0.099 & 0.937 \\
$\sigma_{\mathrm{zt}}$ & 0.00926 & & & & \\
$\sigma_{\mathrm{z}}$ & 0.19353 & & & & \\
$\sigma$ & 0.35099 & & & & \\
\hline
\end{tabular}

Source: Authors.

\section{Discussion}

Corroborating the first hypothesis of our study, numerical and weight abundances of whole shells were significantly greater in the wet sector, where mechanical cleaning is absent. Conversely, the numerical and weight abundance of the fragments was significantly higher in the damp sector, confirming the harsh impacts of cleaning actions using tractors. Steibl and Laforsch (2019) observed a lower abundance of hermit crabs in tourist beaches that undergo mechanical cleaning processes. We observed this also responsible for the fragmentation of empty shells that might otherwise serve as shelter. Thus, we understand an urgent need to establish mitigation measures to preserve shells on Santos beaches, which play an essential role in the coastal ecosystem.

In addition to abundance, the mean and standard deviation of both richness and Shannon-Wiener diversity was higher in the wet sector. We found a significant increase in richness related to the sector with minor impact, following the findings of Griffin (2018). This result also corroborates Stephenson (1999), who found fewer animal species in New Zealand beaches due to cleaning vehicles. Some species are more vulnerable to disturbances than others, explaining the reduction in richness. It is precisely our case: some shells are thinner and more fragile than others and are more fragmented. Tourism itself may also explain, up to some degree, the decreased richness in the damp sector since people remove shells for collection. However, intense tourism is associated with higher frequencies of cleaning operations that cause substantial, often overlooked ecological impacts (Gilburn, 2012; Noriega, 2012; Santos, 2020; Stelling-Wood, 2016; Zielinsk et al., 2019).

Tourism can be a conservation force when sustainable beaches are preferred (Klein et al., 2020; Lindahl et al., 2014; Shao et al., 2017). For instance, Tombo Beach, located at the urban area of Guarujá municipality (an island just across Santos), received the "Blue Flag" (Merino and Prats, 2020) ecological award for satisfying a series of coastal management criteria, including water quality, environmental education, sustainable tourism and not using heavy machinery for cleaning. The city of Guarujá also abandoned the use of tractors at Praia da Enseada a few years ago, where manual cleaning selectively removes harmful debris. Currently, entire shells are found in the sand where newly formed coastal dune vegetation development begins (personal observation).

If not wholly revoked, mechanical cleaning operations might be reduced, given proper management of litter. Nevertheless, litter on Santos beaches comes not only from tourism, but it also has origins in the surrounding slums: it is not uncommon for the people living there too, un-sanitarily and inadequately, disposal of building debris, litter, and organic matter that accumulates in the mangroves close to Santos beaches. Heavy rains and spring tides carry the floating waste accumulated in the mangroves to the beaches, requiring additional clean-up operations. In this context, Barrella et al. (2021) proposed 
installing recycling workshops, contributing to the regional development, and providing income to these people living in such precarious conditions.

According to tides, the dynamics of litter in Santos leads us to the second hypothesis of our study, which was partially corroborated. The comparisons of neap and spring tides showed significantly greater abundances of shells during the latter. However, only numerically higher mean values were found when richness and diversity were taken as the response variables. Griffin (2018), however, found that diversity recovery rate is strongly associated with tide amplitude, favoring higher diversity after spring tides. Such findings suggest that the lack of statistical significance of tide effects in our diversity analyses may be due to the inability of our models to incorporate two antagonistic forces: whilst spring tides act in the reestablishment of shells, which would, thus, promote greater diversity; it also brings the accumulated litter from the mangroves to the beaches, requiring further cleaning, hence removing shells and lowering diversity.

In conclusion, we find it safe to claim a necessary revamp of Santos's current mechanical cleaning procedure, including its frequency according to tide range. Understanding sandy beaches' biodiversity is essential to tackle conservation strategies, environmental education, sustainability measures, and coastline protection. Biodiversity establishes the basis of environmental goods and ecosystem services, fundamental to the survival and well-being of humanity.

\section{Final Considerations}

The shells on Santos beach are disappearing: so, what? It is the response of people when they show disinterest in such evidence. The disappearance of empty shells is one detail of the significant changes caused by human action: an indicator of inappropriate policy that acts on the effect but does not work on the cause. Cleaning the beach is a necessary action, but not the only one. A dynamic collection and recycling system that prevents the inappropriate dumping of the waste of hundreds of thousands of people living in stilt slums in the mangrove swamps of the estuary. The dredging of the channel of the largest port in Latin America accentuates the erosion process at the beach's end and contributes to the disappearance of shells. The heavy machinery used to remove debris and feed the eroded zone of Santos beach causes the fragmentation of shells and the disappearance of plants and animals that live in the drier sand strip. We expected a considered increase in the beach garbage amount generated mainly by the population on stilts which grows at one of the highest rates in the world (6\% per year) (Martins et al., 2021, in press). Given this, the discourse of extinction always emerges as an explanatory and excusing narrative for socio-environmental damage, not only among people in business and government officials but also among ecological and humanitarian organizations. Politicians and business people anticipate sweeping the dirt under the rug to invest in genuinely sustainable solutions. The works are expensive and unseen, so they do not yield votes. Local institutions, educators, technicians, and scientists do not know and disclose the resources' value. What would be the value of some shells on the beach? The importance of a natural resource is easily demonstrated when it is traded with consumption value. However, other types of values are difficult to present, know, evaluate and disclose. For example, the existence value is the concern to keep species, communities, and ecosystems alive. The option value is to keep resources as a potential source of future benefits. Other types of non-consumer values such as productivity, water, and soil protection, climate control, waste purification, recreation, tourism, education, along with the value of beauty, the symbolic value, and the intrinsic interests, complete the list of values still disregarded by society with its current ethical and moral aspects. This scenario is not a local exclusivity. It is also seen in numerous coastal cities worldwide, considering that about $20 \%$ of the world's population lives less than $50 \mathrm{Km}$ from the sea. Knowledge in its details can contribute to the definition and refinement of values and their indicators necessary for authentic, sustainable development. 
More scientific studies need to be carried out on this subject and our intention is to continue contributing to this purpose, including involving other areas of study, comparing beaches that use tractors, with others that clean using more ecologically appropriate methods.

\section{Acknowledgments}

The authors thank Santa Cecília University (UNISANTA), Universidade Paulista (UNIP), Federal University of Pará (UFPA), and Federal University of São João del-Rei (UFSJ), for the partial funding and research facilities.

\section{References}

Absalão, R. S., \& Pimenta, A. D. (2005). Moluscos Marinhos da APA do Arquipélago de Santana, Macaé, RJ. Rio de Janeiro, RJ: Ciência Moderna. (In Portuguese).

Adler, D., \& Thomas Kelly, S. (2019). Vioplot: violin plot. R package version 0.3.4.

Balvanera, P., Pfisterer, A. B., Buchmann, N., He, J. S., Nakashizuka, T., Raffaelli, D., et al. (2006). Quantifying the evidence for biodiversity effects on ecosystem functioning and services. Ecology Letters, 9(10), 1146-1156. https://doi.org/10.1111/j.1461-0248.2006.00963.x

Barrella, W., Farraboti, E., Aparecida Carminatto, A., Chofard Adami, F. A., Rotundo, M. M., Ramires, M., Petrere, Jr M. (2021). The debris distribution model for removal planning of an urbanized estuarine complex. Quaestiones Geographicae, 40(1), 97-107.

Barros, L. R. S. Barrella, W., Petrere Jr., M., \& Butturi-Gomes, D. (2020). Observations of the conchological structure of Santos Beach (Brazil) during the summer of 2020. Mendeley Data. 10.17632/rn7g2tt4vm.1.

Bates, D., Mächler, M., Bolker, B., \& Walker, S. (2015). Fitting Linear Mixed-Effects Models Using lme4. Journal of Statistical Software, 67(1), 1-48. https://doi.org/10.18637/jss.v067.i01.

Bizerril, M. X. A., Louzada, D., Rocha, D. M. S., Peres, J., \& Furoni, G. (2007). Percepção de alunos de ensino fundamental sobre a biodiversidade: relações entre nomes de organismos, mídia e periculosidade, in VI ENPEC - Encontro Nacional de Pesquisa em Educação em Ciências, Florianópolis. Belo Horizonte: ABRAPEC, p. 319. (In Portuguese).

Cardinale, B. J., Srivastava, D. S., Duffy, J. E., Wrigth, J. P., Downing, A. L., Sankaran, M., et al. (2006). Effects of biodiversity on the functioning of trophic groups and ecosystems. Nature, 443 (7114), 989-992. https://doi: 10.1038/nature05202

Conquiliologistas do Brasil (1989). Espécies brasileiras. http://conchasbrasil.org.br/conquiliologia.

Cordeiro, T. C., Barrella, W., Butturi-Gomes, D., \& Petrere Jr, M. A. (2018). A modeling approach for reposition dynamics of litter composition in coastal areas of the city of Santos, Sao Paulo, Brazil. Marine Pollution Bulletin, 28, 333-339. https://doi: 10.1016/j.marpolbul.2018.01.054.

Cordeiro, T. C. (2016). Dinâmica da deposição de resíduos sólidos nas praias de Santos-SP (Dissertação de Mestrado). Universidade Santa Cecília, Santos, SP.

Correia, M. D., \& Sovierzoski, H. H. (2005). Ecossistemas Marinhos: recifes, praias e manguezais. Maceió, AL: Edufal. (In Portuguese).

Defeo, O., McLachlan, A., Schoeman, D. S., Schlacher, T. A., Dugan, J., Jones, A., et al. (2009). Threats to sandy beach ecosystems: a review. Estuarine, Coastal and Shelf Science, 81(1), 1-12. https://doi.org/10.1016/j.ecss.2008.09.022.

Eggers, J. (2015). On Statistical Methods for Zero-Inflated Models.

Gilburn, A. S. (2012). Mechanical grooming and beach award status are associated with low strandline biodiversity in Scotland. Estuarine Coastal and Shelf Science, 107, 81-88. https://doi.org/10.1016/j.ecss.2012.05.004.

Gil, G., Bergonci, P. E. A., Tarasconi, J. C., \& Thomé, J. W. (2010). As conchas de nossas praias. Porto Alegre, RS: Redes Editora.

Griffin, C., Day, N., Rosenquist, H., Wellenreuther, M., Bunnefeld, N., \& Gilburn, A. S. (2018). Tidal range and recovery from the impacts mechanical beach grooming. Ocean and Coastal Management. 154, 66-71. https://doi.org/10.1016/j.ocecoaman.2018.01.004.

Hall-Spencer, J. M., Grall, J., Moore, P. G., \& Atkinson, R. J. A. (2003). Bivalve fishing and maerl-bed conservation in France and the UK - retrospect and prospect. Aquatic Conservation-Marine and Freshwater Ecosystems, 13(S1), S33-S41. https://doi.org/10.1002/aqc.566h.

Hinde, J., \& Demétrio, C. G. B. (1998). Overdispersion: models and estimation. Computational Statistics \& Data Analysis, 27, 151-170.

Kelly, J. F. (2016). Assessing the spatial compatibility of recreational activities with beach vegetation and wrack in New Jersey: prospects for compromise management. Ocean and Coastal Management, 123, 9-17.

Klein, J. S., Petrere Jr., M., Butturi-Gomes, D., \& Barrella, W. (2020). Textile sustainability: A Brazilian etiquette issue, Environmental Science Policy, v. 109, p. $125-130$.

Koche, J. C. (2011). Fundamentos de metodologia científica: teoria da ciência e iniciação à pesquisa. Petrópolis, RJ: Vozes. 
http://www.adm.ufrpe.br/sites/ww4.deinfo.ufrpe.br/files/Fundamentos_de_Metodologia_Cienti\%CC\%81fica.pdf

Kowalewski, M., Serrano, G. E. A, Flessa, K. W., \& Goodfriend, G. A. (2000). Dead delta's former productivity: two trillion shells at the mouth of the Colorado River. Geology, 28(12), 1059-1062. https://doi. org/10.1130/0091-7613(2000)28<1059:DDFPTT>2.0.CO;2.

Lawless, J. F. (1987). Negative binomial and mixed Poisson regression. The Canadian Journal of Statistics, 15(3), 209-225. https://doi.org/10.2307/3314912.

Lindahl, M., Sundin, E., \& Sakao, T. (2014). Environmental and economic benefits of Integrated Product Service Offerings quantified with real business cases. Journal of Cleaner Production, 64, 288-296. 10.1016/j.jclepro.2013.07.047.

Lindner, G. (2000). Moluscos y Caracoles de los mares del mundo. Barcelona, CAT: Ediciones Omega.

Lo, N. C., Jacobson, L. D., \& Squire, J. L. (1992). Indices of Relative Abundance from Fish Spotter Data based on Delta-Lognormal Models. Canadian Journal of Fisheries and Aquatic Sciences, 49(12), 2515-2526. https://doi.org/10.1139/f92-278.

Lopes, C. F., Milanelli, J. C. C., \& Poffo, I. R. F. (2007). Ambientes costeiros contaminados por óleo: procedimentos de limpeza. São Paulo, SP: Secretaria do Estado do Meio Ambiente. Available at: https://pt.scribd.com/document/327931169/ambientes-costeiros

Magini, C., Harari, J., \& Abessa, D. M. S. (2007). Circulação recente de sedimentos costeiros nas praias de Santos durante eventos de tempestades: dados para a gestão de impactos físicos costeiros. Geociências, 26(4), 349-355. (In Portuguese).

Martins, F. L. C., Giordano, F., \& Barrella, W. (2021 in press). Socio-Environmental vulnerability of water in the estuary of the metropolitan region of Santos (Brazil). Quaestiones Geographiceae (Accept Manuscript QG-D-20-00058R1).

Merino, F. \& Prats, M. A. (2020). Sustainable beach management and promotion of the local tourist industry: Can blue flags be a good driver of this balance? Ocean \& Coastal Management, (198) 1.

Michel, J., Shigenaka, G., \& Hoff, R. (1992). Oil Spill Response and Clean up Techniques. In: An Introduction to Coastal Habitats and Biological Resources for Oil Spill Response. Seattle, WA.

Milanelli, J. C. C., \& Lopes, C. F. (2001). Recuperação de praias atingidas por derrames de óleo - procedimentos emergenciais adotados pela CETESB, in 14a Semana Nacional de Oceanografia - Oceanografia e Sociedade: Um desafio à Teoria e Prática. Rio Grande, RS. (In Portuguese).

Min, Y., \& Agresti, A. (2002). Modeling Nonnegative Data with Clumping at Zero: A Survey Models for Semicontinuous Data This section introduces some methods for modeling semicontinuous. Journal of The Iranian Statistical Society, 1(1-2), 7-33.

Moral, R. A., Hinde, J., \& Demétrio, C. (2017). Half-Normal Plots and Overdispersed Models in R: The hnp Package. Journal of Statistical Software, 81(10), 1-23. https://doi.org/10.18637/jss.v081.i10

Moser, G. A. O., Gianesella, S. M. F., Barreraalba, J. J., Bergamo, A. L., Saldanha Correa, F. M. P., Miranda, L. B., et al. (2005). Instantaneous transport of salt, nutrients, suspended matter and chlorophyll-a in the tropical estuarine system of Santos. Brazilian Journal of Oceanography, 53(3/4), 115-127.

Morton, J. K., Ward, E. J., \& Berg, K. C. (2011). Potential Small- and Large-Scale Effects of Mechanical Beach Cleaning on Biological Assemblages of Exposed Sandy Beaches Receiving Low Inputs of Beach-Cast Macroalgae. Journal of Coastal Research, 27(6), 184-192.

Noriega, R., Schlacher, T. A., \& Smeuninx, B. (2012). Reductions in Ghost Crab populations reflect urbanization of beaches and dunes. Journal of Coastal Research, 28 (1), 123-131.

O'Connor, N. E., \& Crowe, T. P. (2005). Biodiversity loss and ecosystem functioning: Distinguishing between number and identity of species. Journal of Ecology, 86(7), 1783-1796. https://doi.org/10.1890/04-1172.

Pimentel-Gomes, F. (2009). Curso de Estatística Experimental. Edited by 15. Piracicaba: FEALQ. (In Portuguese).

Pinheiro, J. C., \& Bates, D. M. (2000). Mixed-Effects Models in S and S-Plus. New York: Springer-Verlag.

Prefeitura Municipal de Santos. (2019). Serviço de limpeza das praias. https://www.santos.sp.gov.br/?q=servico/limpeza-das-praias

Ramírez, R., Tuya, F., \& Haroun, R. J. (2008). Efectos potenciales del marisqueo sobre moluscos gasterópodos de interés comercial (Osilinus spp. y Patella spp.) en el Archipiélago Canario. Revista de Biologia Marina y Oceanografia, 44, 603-714. https://doi.org/10.4067/S0718-19572009000300016.

R Core Team (2019). R: A Language and Environment for Statistical Computing. Vienna: R Foundation for Statistical Computing.

Ruiz, Y. S., \& Barrella, W. (2014). Saída de Campo em Costão Rochoso no Ensino da Biotecnologia de Crustáceos Decápodes. UNISANTA BioScience, 102-106. (In Portuguese).

Santos, T. M. T. (2020). Efeitos das atividades recreacionais sobre a fauna bentônica em praias arenosas amazônicas [PhD Thesis]. Universidade Federal do Pará, Belém, PA. (In Portuguese).

Shao, J., Taisch, M., \& Mier, M. O. 2017. Influencing factors to facilitate sustainable consumption: from the experts' viewpoints. J. Clean. Prod. 142, 203216.

Steibl, S., \& Laforsch, C. (2019). Disentangling the environmental impact of different human disturbances: a case study on islands. Scientific Reports. $10.1038 / \mathrm{s} 41598-019-49555-6,9,1$.

Stelling-Wood, T. P., Clarck, G. F., \& Poore, A. G. (2016). Responses of ghost crabs to habitat modification of urban sandy beaches. Marine Environmental Research, 116, 32-40. https://doi.org/10.1016/j.marenvres.2016.02.009. 
Research, Society and Development, v. 10, n. 14, e130101421733, 2021

(CC BY 4.0) | ISSN 2525-3409 | DOI: http://dx.doi.org/10.33448/rsd-v10i14.21733

Stephenson, G. Vehicle impacts on the biota of sandy beaches and coastal dunes: a review from a New Zealand perspective. Dept. of Conservation. Wellington, New Zealand. 1999.

Van Der Sancia, E. T., Moolenbeek, R. G., \& Hoeksema, B. W. (2009). Decline of the Jakarta Bay molluscan fauna linked to human impact. Marine Pollution Bulletin, 59(4-7), 101-017. https://doi.org/10.1016/j.marpolbul.2009.02.021.

Zielinski, S., Botero, C. M., e A. Y. (2019). To clean or not to clean? A critical review of beach cleaning methods and Impacts. Marine Pollution Bulletin, 139(390-401). https://doi.org/10.1016/j.marpolbul.2018.12.027. 